\title{
Correction to: Economic burden of multiple sclerosis in a population with low physical disability
}

José M. García-Domínguez ${ }^{1}$, Jorge Maurino ${ }^{2 *}$, María L. Martínez-Ginés ${ }^{1}$, Olga Carmona ${ }^{3}$, Ana B. Caminero ${ }^{4}$, Nicolás Medrano ${ }^{2}$, Elena Ruíz-Beato ${ }^{5}$ and for the W-IMPACT Clinical Investigators

\section{Correction to: BMC Public Health https://doi.org/10.1186/s12889-019-6907-x}

It has been highlighted that the original article [1] contained a mistake in the 'Results' section, specifically in the percentages of female subjects and those with diagnosis of RRMS. Please note that this mistake has only been present in the 'Results' section, the Abstract and Table 1 remain unchanged. This article shows the incorrect and correct version of the percentages.

\section{Incorrect:}

Subjects were predominantly female (60.2\%), with a diagnosis of RRMS (86.1\%) and a mean age of $43.9 \pm 10.5$ years.

\section{Correct:}

Subjects were predominantly female (60.8\%), with a diagnosis of RRMS (86.4\%) and a mean age of $43.9 \pm 10.5$ years.

\section{Author details \\ ${ }^{1}$ Department of Neurology, Hospital Universitario Gregorio Marañón, Madrid, Spain. ${ }^{2}$ Medical Department, Roche Farma, Ribera del Loira, 50, 28042 Madrid, Spain. ${ }^{3}$ Department of Neurology, Hospital de Figueres, Figueres, Spain. ${ }^{4}$ Department of Neurology, Hospital Nuestra Señora de Sonsoles, Complejo Asistencial de Ávila, Avila, Spain. ${ }^{5}$ Health Economics and Outcomes Research Unit, Roche Farma, Madrid, Spain.}

Received: 3 July 2019 Accepted: 3 July 2019

Published online: 08 July 2019

\section{Reference}

1. García-Domínguez, et al. Economic burden of multiple sclerosis in a population with low physical disability. BMC Public Health. 2019;19:609. https://doi.org/10.1186/s12889-019-6907-x.

\footnotetext{
* Correspondence: jorge.maurino@roche.com

${ }^{2}$ Medical Department, Roche Farma, Ribera del Loira, 50, 28042 Madrid, Spain

Full list of author information is available at the end of the article
}

(c) The Author(s). 2019 Open Access This article is distributed under the terms of the Creative Commons Attribution 4.0 International License (http://creativecommons.org/licenses/by/4.0/), which permits unrestricted use, distribution, and reproduction in any medium, provided you give appropriate credit to the original author(s) and the source, provide a link to the Creative Commons license, and indicate if changes were made. The Creative Commons Public Domain Dedication waiver (http://creativecommons.org/publicdomain/zero/1.0/) applies to the data made available in this article, unless otherwise stated. 